Published in the Journal of Modern European History 18, no. 3 (2020), 237-242

https://doi.org/10.1177/1611894420927213

\title{
'I Am Not a Politician’: Professional Boundary Work in Wilhelmine Germany
}

\author{
Herman Paul \\ Leiden University
}

Heinrich von Sybel, one of the mightiest men in 19th-century German historical studies, once remarked that his Munich colleague Johann Kaspar Bluntschli served the national cause with even greater intensity than he himself. Whereas Sybel described himself as 'four-seventh of a professor and three-seventh of a politician', he saw this ratio inverted in Bluntschli: 'You are four-seventh of a politician and three-seventh of a professor. ${ }^{\prime 1}$ Other German historians of the time made similar calculations, sometimes with more spectacular results. Heinrich von Treitschke, for instance, confided in Gustav Freytag that 'the patriot in me is a thousand times starker than the professor'. ${ }^{2}$ Apparently, historians from Sybel's generation did not exactly perceive the professor and the politician as mutually exclusive role-identities, although the roles could be distinguished and even quantified.

For a generation born in Vormärz Germany, this was hardly surprising. Many German historians in and around the time of 1848 conceived of themselves as 'constructors of the nation' and wanted to put their historical work into the service of national unification. ${ }^{3}$ Such 'political professors' continued to exist even after 1871. In 1880s Berlin, Sybel taught his students that historians had to be researchers, political experts, and artists rolled into one. ${ }^{4}$ At the same time, however, the model of the political professor came under pressure from scholars who felt that Sybel's and Treitschke's political enthusiasm hindered the pursuit of objective historical knowledge. Although Georg Waitz, a leading figure in the Monumenta

\footnotetext{
${ }^{1}$ Quoted in C. Varrentrapp, "Biographische Einleitung", in: H. von Sybel, Vorträge und Abhandlungen, ed. C. Varrentrapp, Munich 1897, 1-156, at 128.

2 Heinrich von Treitschke to Gustav Freytag, 13 November 1865, in: Gustav Freytag und Heinrich von Treitschke im Briefwechsel, ed. A. Dove, Leipzig 1900, 69-75, at 72.

${ }^{3}$ N. Lenhard-Schramm, Konstrukteure der Nation: Geschichtsprofessoren als politische Akteure in Vormärz und Revolution 1848/49, Munster 2014.

${ }^{4}$ H. v[on] Sybel, "Georg Waitz", in: Historische Zeitschrift 56 (1886), 482-487, at 484.
} 
Germaniae Historica, had been a committed member of the Frankfurt Parliament, he drew increasingly sharper lines between the responsibilities of the historian and those of the politician. ${ }^{5}$ This led younger scholars such as Ernst Bernheim to emphasize that someone with strongly developed political interests would be unsuited for a historian's career. Historical scholarship required other dispositions than political work. ${ }^{6}$

What these examples reveal is that the figure of the politician not only mattered to politicians themselves, or to their voters; the figure also served as a point of reference in other fields, such as historical scholarship. Historians talked quite a bit about the marks of a politician, precisely because they were divided over the question of how much a historian had to resemble a politician. This opens up some interesting questions, on which I will touch briefly in the pages that follow: What were the traits that historians associated with the figure of the politician? Why were they so keen to compare themselves, positively or negatively, to politicians? How unique were German historians in performing such boundary work? And why would it matter, from a historiographical point of view, to study the persona of the politician through the lens of people who emphatically declared: 'I am not a politician'?

\section{Political passion}

In Vormärz Germany, 'historian' and 'politician' were different but still compatible role identities. Writing in 1836, Leopold von Ranke described their difference merely in terms of aims ('one suffices simply to preserve, the other passes beyond preservation to the creation of something new'), and not in terms of abilities or dispositions. ${ }^{7}$ If this phrasing allowed individuals to pursue both aims simultaneously, Ranke struck a different tone when, some 40 years later, he wrote to Otto von Bismarck that 'a historian can never at the same time be a practicing politician' ${ }^{8}$ By 1877 , it had become increasingly common to conceive of history

\footnotetext{
${ }^{5} \mathrm{H}$. Paul, "The Virtues of a Good Historian in Early Imperial Germany: Georg Waitz's Contested Example", in: Modern Intellectual History 15 (2018), 681-709.

${ }^{6}$ E. Bernheim, Lehrbuch der historischen Methode: Mit Nachweis der wichtigsten Quellen und Hülfsmittel zum Studium der Geschichte, Leipzig 1889, 507.

${ }^{7}$ L. von Ranke, "On the Relation of and Distinction between History and Politics" (1836), in: idem, The Theory and Practice of History, ed. G. G. Iggers, London 2011, 75-82, at 81. 8 Leopold von Ranke to Otto von Bismarck, 22 February 1877, in: Ranke, Das Briefwerk, ed. W. P. Fuchs, Hamburg 1959, 546-547, at 546.
} 
and politics, not as complementary activities, but as vocations that made different demands on the self. In Ranke's letter to Bismarck, this change of perspective is visible in an admiring comment on the chancellor's 'virtuosity' - a character trait that badly fitted the contemplative figure of the historian as envisioned by the Berlin Altmeister.

Several factors help to explain why historians in the early German Empire reconfigured the classic issue of 'history and politics' into a question about vocation-specific qualities. Perhaps the most important of these was the growing importance of political eloquence and rhetorical cogency for members of a parliament that increasingly served as an arena for public debate. ${ }^{9}$ If this helped to mould a new type of politician, historians at the same time witnessed the emergence of a 'professional' type of historian that critics denounced as an Urkundion or Zunftgelehrte - someone who spent a lifetime editing medieval sources without ever reaching out to audiences beyond the circle of fellow specialists. Protracted debates over the 'first commandment', 'highest duty' or 'highest virtue' for historians illustrate that politicians were not the only ones who reflected on their work in terms of vocation-specific qualities. ${ }^{10}$ In this context, politicians increasingly saw 'political passion' (politische Leidenschaft) as a key to effective rhetorical performance. Accordingly, they portrayed charismatic figures such as Heinrich von Gagern as political orators who were able to unleash enormous passion, while depicting August Bebel, the social democratic leader, as a man driven by pure Leidenschaft. ${ }^{11}$ Following Treitschke, who cherished political passion as 'a precious treasure', ${ }^{12}$ historians also developed a habit of perceiving politicians as men of passion. Alfred Dove, for instance, spoke about 'the passion of a real politician' and the 'passionate disposition' that was needed for political success. ${ }^{13}$ Several historians commented on

\footnotetext{
${ }^{9}$ H.-P. Goldberg, Bismarck und seine Gegner: Die politische Rhetorik im kaiserlichen Reichstag, Düsseldorf 1998, 521, 524, 527.

${ }^{10} \mathrm{H}$. Paul, "A Missing Link in the History of Historiography: Scholarly Personae in the World of Alfred Dove", in: History of European Ideas 45 (2019), 1011-1028.

${ }^{11}$ F. Möller, "Heinrich von Gagern: Charisma und Charakter", in: idem (ed.), Charismatische Führer der deutschen Nation, Munich 2004, 43-61, at 58; Goldberg, Bismarck und seine Gegner, 153-158.

12 H. von Treitschke, "Das constitutionelle Königthum in Deutschland (Heidelberg 1869-71)", in: idem, Historische und politische Aufsätze, vol. 3, Leipzig 1871, 491-625, at 625.

${ }^{13}$ A. Dove, "Johann Gustav Droysen", in: Im neuen Reich 8 (1878), 105-118, at 111; A. Dove, "Freytag, Gustav", in: Allgemeine Deutsche Biographie, vol. 48, Leipzig 1904, 749-767, at 754.
} 
Treitschke's characteristic passion for politics or confirmed the intimate relation between politics and passion by explaining why Johann Gustav Droysen had been a poor parliamentary speaker: 'the powerful thrusts of passionate debates' did not match his finely strung temperament. ${ }^{14}$ (Interestingly, none of these historians anticipated Max Weber's argument that politicians need not only passionate commitments, but also and just as importantly, a sense of proportion that restrains and channels their passion. ${ }^{15}$ Emotional detachment was not among the features that 19th-century historians associated with the figure of the politician.)

Just like other, less dominant images that circulated among German historians - the politician as a party man, for instance, who as such could never be impartial in his judgment ${ }^{16}$-, this near-exclusive emphasis on Leidenschaft caused potentially serious friction between the politician and the historian, at least insofar as the latter was expected to practice an ascetic kind of objectivity. Dissatisfied with Sybel and Treitschke, both of whose attempts to keep the historian and the politician close together resulted in rather patriotic forms of history writing, historians who cared about the Wissenschaftlichkeit of historical studies increasingly turned the politician into an 'other' - that is, into someone who embodied qualities that historians should better avoid.

\section{Boundary work}

Unsurprisingly, the politician as an 'other' emerged most visibly in debates over the pros and cons of the kind of historian that Sybel and Treitschke had embodied. Characteristic of late 19th-century debates over the virtues that historians had to display is that they were focused on competing models of virtue. Instead of quarrelling in the abstract about

See also E. Marcks, "Einleitung", in: H. Baumgarten, Historische und politische Aufsätze und Reden, ed. E. Marcks, Strasburg 1894, v-cxxxiv, at xviii.

${ }^{14}$ M. Lenz, Heinrich von Treitschke: Ansprache an die Berliner Studentenschaft bei ihrer Trauerfeier am 17. Mai 1896, Berlin 1896, 4; G. Schmoller, "Gedächtnisrede auf Heinrich von Sybel und Heinrich von Treitschke: Gehalten in der Leibnizsitzung der Akademie der Wissenschaften in Berlin am 2. Juli 1896", in: Forschungen zur Brandenburgischen und Preußischen Geschichte 9 (1897), 357-394, at 371; M. Duncker, "Johann Gustav Droysen", in: Preußische Jahrbücher 54 (1884), 134-167, at 153.

${ }^{15}$ M. Weber, Politik als Beruf, Munich 1919, 50.

${ }^{16}$ H. Baumgarten, "Treitschke's Deutsche Geschichte", in: Allgemeine Zeitung (6 December 1882), 5009-5010, at 5010; C. Varrentrapp, "Zur Erinnerung an Friedrich Christoph Dahlmann", in: Preußische Jahrbücher 55 (1885), 485-510, at 501. 
objectivity, historians debated more concretely about the attractiveness of objectivity as embodied by Ranke. Likewise, in debates about patriotism as a historiographical virtue, they invoked the model of Sybel or Treitschke, just as they routinely treated Johannes Janssen, the Catholic apologist, as an incarnation of dogmatism. Ranke, Treitschke, and Janssen thereby served as 'personae' that embodied, often in a slightly exaggerated form, competing models of how (not) to be a historian. ${ }^{17}$

In very similar ways, professional identities such as the 'politician', the 'artist', and the 'judge' served as rhetorical figures that helped scholars to navigate competing models of how to be a historian. Although these did not allow for identification in the same way that Ranke and Treitschke did, they also embodied particular virtues, qualities or talents. If the politician represented political passion, the 'gifts of the artist' included 'the power of flourishing fantasy, subtlety of perception, the intuitive gaze'. ${ }^{18}$ In its turn, the judge was mostly invoked as a moral arbiter: someone called to identify right and wrong in human endeavours. ${ }^{19}$

Like the artist and the judge, the politician played a crucial role in historians' professional boundary work (perhaps even more so in the politicized world of early Imperial Germany). By contrasting the historian and the politician - 'he was not a man of politics, not a statesman, but a man of science', as Ludwig Weiland declared about Waitz -, it was implied that a historian who resembled a politician too much had become 'disloyal to his vocation' ${ }^{20}$ Likewise, historians who gave too much rein to their artistic inclinations were perceived as betraying their professional identity: They had forgotten that historians, unlike artists, had to restrain their imagination so as to stay loyal to the historical record. ${ }^{21}$ So, just as historians invoked Ranke, Treitschke, and others as embodied models of how (not) to be a

\footnotetext{
${ }^{17}$ I elaborate on the concept of 'personae' in: H. Paul, "Introduction: Scholarly Personae: What They Are and Why They Matter", in: idem (ed.), How to Be a Historian: Scholarly Personae in Historical Studies, 1800-2000, Manchester 2019, 1-14.

${ }^{18}$ P. Bailleu, "Heinrich von Treitschke", in: Deutsche Rundschau 85 (1895), 41-76, at 50.

${ }^{19}$ G. Weber, "Friedrich Christoph Schlosser", in: Unsere Zeit 6 (1862), 314-326, at 326.

${ }^{20}$ L. Weiland, Georg Waitz (geb. 9. October 1813, gest. 24. Mai 1886): Rede gehalten in der öffentlichen Sitzung der K. Gesellschaft der Wissenschaften am 4. Dezember 1886, Göttingen 1886, 13-14; K. Lamprecht, "Eine Festrede”, in: Die Zukunft 26 (1899), 137-143, at 138. ${ }^{21}$ Bernheim, Lehrbuch, 89; O. Lorenz, Die Geschichtswissenschaft in Hauptrichtungen und Aufgaben kritisch erörtert, vol. 2, Berlin 1891, 342-343.
} 
historian, their rhetorical positioning of the politician vis-à-vis the historian revealed how they perceived of the demands that historical scholarship made on the self.

\section{Professional role identities}

Clearly, then, the identity of the politician was relevant not only to politicians themselves, or to their voters, but also to participants in other cultural fields, such as historical scholarship. The persona of the politician - my technical term for the vocation-specific qualities that people attribute to politicians at a given time and place - mattered well beyond the Reichstag and Germany's political parties. People in other cultural fields also needed the politician, even if only as a strawman, to articulate how they understood their own role identities.

This phenomenon can also be observed in other academic disciplines. As early as 1862, the legal scholar Rudolf von Jhering found it necessary to declare: 'I am a man of civil law, I am not a politician. ${ }^{22}$ When commemorating Georg von Gizycki, a Berlin professor with social-democratic sympathies, Otto Mittelstädt pointed out that Gizycki had been a careful-thinking philosopher, 'not a politician'. ${ }^{23}$ Likewise, in the military, generals such as Hermann von Boyen and Siegmund von Pranckh who also served as ministers of war in Prussia and Bavaria respectively, distanced themselves from all political intrigue by emphasizing that they had been soldiers instead of politicians, judging the world with 'healthy common sense'. ${ }^{24}$ Finally, as Tobias Weidner has recently demonstrated, medical doctors also habitually dissociated themselves from pathologized images of the politician that they perceived as characterized by fanaticism, agitation and partiality, amongst other things. ${ }^{25}$ (It would be worth examining to what extent these professional reservations vis-à-

\footnotetext{
22 [Rudolf von] Jhering, stenogram of an untitled speech in Verhandlungen des Dritten Deutschen Juristentages, vol. 1, Berlin 1862, 10-19, at 13.

${ }^{23}$ O. Mittelstädt, "Georg von Gizycki", in: Die Zukunft 11 (1895), 438-443, at 441.

${ }^{24}$ Erinnerungen aus dem Leben des General-Feldmarschalls Hermann von Boyen, ed. F. Nipold, vol. 1, Leipzig 1889, 404; H. Schulthess / W. Oncken, Chronik und geschichtliche Uebersicht der denkwürdigen Jahre 1870 und 1871, vol. 1, Nördlingen 1872, 202.

${ }^{25}$ T. Weidner, Die unpolitische Profession: Deutsche Mediziner im langen 19. Jahrhundert, Frankfurt am Main 2012.
} 
vis the figure of the politician paved the way for a more general denunciation by later cultural critics such as Werner Sombart and Thomas Mann. $)^{26}$

Evidently, such 'unpolitical' self-fashioning served self-legitimizing purposes in that it justified types of work that were not as visionary or emotional as political life supposedly was. Accordingly, in contexts like these, the rhetorical figure of the politician served as an 'other' that could not be imitated too closely. Interpreted against the larger background of (academic, military, political) professions that emerged in the 19th century, such rhetorical boundary work can also be seen as attempts to negotiate various forms of distance and proximity between fields that defined themselves mainly by distinguishing themselves from one another.

\section{Conclusion}

Precisely to the extent, then, that the politician was a figure with relevance outside of the political arena, it allows historians to trace the qualities that were associated to it well beyond the political domain. Research on political personae is not only relevant for historians who are interested in how different prime ministers or members of parliaments embodied different ways of being a politician. Because the figure of the politician was also invoked outside of the political realm, as a role identity to which professionals in various cultural fields related, research on political personae has the potential of bringing the history of political culture into productive interaction with neighbouring fields of history.

Arguably, such interaction would benefit from more sustained inquiry into the impact of stereotypical images of the politician on members of parliament themselves, especially at a time when the emergence of the Berufspolitiker fuelled debate on the qualities needed for a political career. ${ }^{27}$ And the other way around: What influence, if any, did the emergence of 'professional politicians' of the kind that Bismarck had feared have on the public image of politicians being characterized primarily by passion? Moreover, it would be relevant to

${ }^{26}$ K. Palonen, "Sombart and Weber on Professional Politicians", in: Max Weber Studies 5.2/6.1 (2005/2006), 33-50; J. Andres, "'Politik' in der konservativen deutschen Kulturkritik: Paul de Lagarde, August Julius Langbehn, Thomas Mann", in: W. Steinmetz (ed.), "Politik": Situationen eines Wortgebrauchs im Europa der Neuzeit, Frankfurt am Main 2007, 339-361. ${ }^{27}$ K. Palonen, Rhetorik des Unbeliebten: Lobreden auf Politiker im Zeitalter der Demokratie, Baden-Baden 2012, 29-53; see also A. Biefang, Der andere Seite der Macht: Reichtstag und Öffentlichkeit im "System Bismarck" 1871-1890, Düsseldorf 2009, 163-175. 
examine how the persona of the politician, both within and outside of the political realm, changed from the late 19th century onwards under influence of, for instance, extensions of suffrage. Last but not least, whereas the Prussian historians with whom I started - Sybel and Treitschke - had no trouble agreeing with Droysen that an unpolitical historian amounted to an 'eunuch', later generations, by contrast, embraced modes of masculinity from which the political was expressly excluded. ${ }^{28}$ For this reason, the gender aspects of the political persona might warrant some scholarly attention, too. ${ }^{29}$

${ }^{28}$ F. Schnicke, Die männliche Disziplin: Zur Vergeschlechtlichung der deutschen Geschichtswissenschaft 1780-1900, Göttingen 2015, 412-442.

${ }^{29}$ See, however, S. Kaduk, “'...die zarten Künste der Damenpolitik': Zur geschlechtlichen Dimension des Politischen in der deutschsprachigen Nationalhistoriographie", in: Steinmetz (ed.), "Politik", 314-338. 
